\title{
Use of a Noninvasive Brain-Penetrating Peptide-Drug Conjugate Strategy to Improve the Delivery of Opioid Pain Relief Medications to the Brain
}

\author{
Émilie Eiselt, Valérie Otis, Karine Belleville, Gaoqiang Yang, Alain Larocque, Anthony Régina, \\ Michel Demeule, (1) Philippe Sarret, and 느ouis Gendron
}

\begin{abstract}
Département de pharmacologie-physiologie, Institut de pharmacologie de Sherbrooke, Centre de Recherche du Centre Hospitalier Universitaire de Sherbrooke, Faculté de médecine et des sciences de la santé, Université de Sherbrooke, Sherbrooke, Québec, Canada (É.E., V.O., K.B., P.S., L.G.); Angiochem Inc., Montréal, Québec, Canada (G.Y., A.L., A.R., M.D.); and Quebec Pain Research Network, Sherbrooke, Québec, Canada (P.S., L.G.)
\end{abstract}

Received November 3, 2019

\begin{abstract}
The analgesic potency of morphine-6-glucuronide (M6G) has been shown to be 50 -fold higher than morphine after intracerebral injection. However, the brain penetration of M6G is significantly lower than morphine, thus limiting its usefulness in pain management. Here, we created new entities by the conjugation of the angiopep-2 peptide (An2) that crosses the blood-brain barrier (BBB) by low-density lipoprotein receptor-related protein 1 receptor-mediated transcytosis with either morphine or M6G. We demonstrated improvement of BBB permeability of these new entities compared with that of unconjugated M6G and morphine. Intravenous or subcutaneous administration of the An2-M6G conjugate exerted greater and more sustained analgesic activity than equivalent doses of either morphine or M6G. Likewise, subcutaneous An2-morphine induced a delayed but prolonged antinociceptive effect. The effects of these conjugates on the gastrointestinal tract motility were also evaluated. An2-morphine significantly reduced the intestinal transit time, whereas An2-M6G exhibited a reduced constipation profile, as
\end{abstract}

compared with an equimolar dose of morphine. In summary, we have developed new brain-penetrant opioid conjugates exhibiting improved analgesia to side effect ratios. These results thus support the use of An2-carrier peptides as an innovative BBB-targeting technology to deliver effective drugs, such as M6G, for pain management.

\section{SIGNIFICANCE STATEMENT}

The metabolite morphine-6-glucuronide (M6G) does not efficiently cross the blood-brain barrier. The low-density lipoprotein receptor-related protein 1 peptide ligand angiopep-2 may serve as an effective drug delivery system to the brain. Here, we demonstrated that the coupling of M6G to angiopep-2 peptide (An2) improves its brain penetration and significantly increases its analgesic potency. The An2-M6G conjugate has a favorable side effect profile that includes reduction of developing constipation. An2-M6G exhibits a unique pharmacodynamic profile with a better therapeutic window than morphine.

\section{Introduction}

Despite important research efforts, the relief of moderate to severe pain still relies on opioids. Indeed, since 1986, the World Health Organization has identified morphine as the most suitable drug for the management of moderate to severe

This work was supported by a Foundation Grant from the Canadian Institute of Health Research (CIHR) awarded to P.S. (Grant FDN-148413) and by a CIHR grant awarded to L.G. (Grants MOP-123399 and MOP-136871). P.S. holds a Canada Research Chair in Neurophysiopharmacology of Chronic Pain. L.G. is the recipient of Senior Salary support from the Fonds de la Recherche Québec-Santé.

Conflict of interest: The new chemical entities described herein are proprietary to Angiochem Inc. M. D., A.R., G.Y., and A.L. were employees of Angiochem Inc., and are listed on company patent applications. P.S. has received research funding and consulting fees from Angiochem Inc. L.G. has received research funding from Angiochem Inc.

https://doi.org/10.1124/jpet.119.263566. pain (Mercadante and Fulfaro, 2005). In addition to inducing profound analgesia, opioids are well-known to interfere with numerous physiologic functions. At the peripheral level, most commonly used opioids, including morphine, activate the $\mu$ opioid receptor in the gut, thus producing constipation, one of the main adverse effects of opioids (Bhimji and Whitten, 2018). Although morphine produces potent analgesia, high systemic doses are also needed because of the development of tolerance and its limited brain penetration, thus further increasing the incidence of adverse events (Oldendorf et al., 1972). Improving morphine and derivatives to cross the bloodbrain barrier (BBB) could thus be key to increasing analgesia while reducing the peripheral adverse effects.

Previous studies have established the mechanism of action for morphine as well as its metabolism and disposition (De Gregori et al., 2012; Sverrisdóttir et al., 2015). Morphine is rapidly

ABBREVIATIONS: An2, angiopep-2 peptide; AUC, area under the curve; BBB, blood-brain barrier; DIEA, $N, N$-diisopropylethylamine; DMF, dimethylformamide; ESI, electron spray ionization; HPLC, high-performance LC; HRMS, high-resolution mass spectrometry; LC, liquid chromatography; LRP1, low-density lipoprotein receptor-related protein 1; M3G, morphine-3-glucuronide; M6G, morphine-6-glucuronide; m/z, mass-to-charge ratio; MeCN, acetonitrile; MPE, maximum possible effect; P-gp, P-glycoprotein; TFA, trifluoroacetic acid; UGT, UDPglucuronosyltransferase; UPLC, ultra-performance LC; $\mathrm{V}_{\mathrm{d}}$, distribution volume. 
metabolized in the liver by the UDP-glucuronosyltransferase (UGT) enzyme. The major metabolite of morphine is morphine3-glucuronide (M3G), whereas a smaller portion is converted to morphine-6-glucoronide (M6G) (De Gregori et al., 2012). After oral administration in human, the ratio of each metabolite to morphine is 9:1 and 50:1, respectively, for M6G and M3G (Osborne et al., 1990). The addition of a glucuronide significantly increases the polarity of morphine and therefore facilitates its excretion in urine. In general, a single subcutaneous dose of morphine is excreted at $85 \%$ after 24 hours, with $75 \%$ in glucuronidated forms and only $10 \%$ in nonmetabolized form (Yeh, 1975). It has been shown that these two morphine metabolites differ profoundly in the management of pain. Several studies strongly suggest that M3G is a physiologic antagonist for the analgesic effect of morphine (Shimomura et al., 1971; Andersen et al., 2003). Although the exact mechanisms remain unclear, M3G is thought to be largely responsible for the phenomenon of morphine-induced hyperalgesia (Smith, 2000; Shavit et al., 2005; Due et al., 2012; Roeckel et al., 2017). In addition, there is evidence to support the role of M3G in the development of morphine tolerance (Lipkowski et al., 1994; Smith and Smith, 1995). Conversely, M6G exhibits a high analgesic potency (typically more than 50-fold that of morphine) after direct administration into the cerebral ventricles (intracerebroventricular injection), thus bypassing the BBB (Pasternak and Pan, 2013). Despite their high polarity and their low expected lipophilicity, multiple pieces of evidence suggest that M3G and M6G can barely cross the BBB (Yoshimura et al., 1973; Carrupt et al., 1991; Smith, 2000). Accordingly, the BBB penetration of morphine is approximately 30-50 times higher than that of M6G (Bickel et al., 1996; Wu et al., 1997). On the other hand, the passive transport of morphine across the BBB and/or its transporter-facilitated (active) passage have not yet been completely elucidated. However, various strategies have been proposed to improve the brain uptake of therapeutic agents, including delivery through active transporters or receptor-mediated transcytosis (Régina et al., 2008; Bertrand et al., 2010; Banks, 2016).

Given the high analgesic potency of M6G, without induction of the M3G metabolite that antagonizes the analgesic effect of morphine, M6G could be a promising drug to treat moderate to severe pain. The major issue of systemic use of M6G is its poor $\mathrm{BBB}$ permeability. In this study, we proposed to increase the $\mathrm{BBB}$ penetration of $\mathrm{M} 6 \mathrm{G}$ and morphine by conjugation to the shuttle angiopep-2 peptide (An2). We have previously shown the advantage of An2 coupling in terms of improving brain delivery to treat pain (Demeule et al., 2008, 2014; Eiselt et al., 2019). Here, we thus investigated the potential therapeutic benefits of An2-morphine and An2-M6G after systemic administration in a rodent model of nociception as well as on the motility of the gastrointestinal tract.

\section{Materials and Methods}

Compounds Synthesis and Conjugation. M6G (compound 4) was prepared as described elsewhere (Lacy and Sainsbury, 1995; Rukhman et al., 2001). $N$-succinimidyl-3-(2-pyridyldithio)propionate was purchased from TRC, Toronto. All other reagents and anhydrous solvents were purchased from Sigma-Aldrich (St. Louis, MO) and used as received. NMR $\left({ }^{1} \mathrm{H},{ }^{13} \mathrm{C}\right)$ spectra were recorded on Varian AS600 spectrometers (Palo Alto, CA) in deuterated chloroform, deuterated methanol, or DMSO with solvent resonance as the internal standard. Low- and high-resolution mass spectra were recorded on Bruker microTOF spectrometers (Billerica, MA) using electron spray ionization (ESI). The purity of the conjugate target compounds was determined to be $>95 \%$ by ultra-performance liquid chromatography (UPLC)/mass spectrometry on a Waters Acquity UPLC spectrometer (Milford, MA) and by high-performance liquid chromatography (HPLC) on a Shimadzu SCL-10A HPLC (Columbia, MD). UPLC was conducted on an Acquity UPLC BEH phenyl $1.7-\mu \mathrm{m}$ column $(2.1 \times 50 \mathrm{~mm})$ using a gradient of $10 \%-90 \% \mathrm{MeCN}$-water $(0.1 \%$ formic acid) at $0.5 \mathrm{ml} / \mathrm{min}$. HPLC was conducted on a Taxsil $3-\mu \mathrm{m}$ column $(4.6 \times 50 \mathrm{~mm})$ using a gradient of $10 \%-70 \% \mathrm{MeCN}$-water $(0.05 \% \mathrm{TFA})$ at $1 \mathrm{ml} / \mathrm{min}$. Analytical thin-layer chromatography was performed on Merck $60 \mathrm{~F}$ 254 precoated silica gel plates. Flash column chromatography was performed on a Biotage system (Charlottesville, VA) using Silicycle siliaflash cartridges (230-400 mesh). Purifications were performed with a phenyl column on a Waters PrepLC 4000 system.

Compound 2: Benzotriazol-1-yl-oxytripyrrolidinophosphonium hexafluorophosphate (0.52 g, $1.0 \mathrm{mmol})$ and DIEA (0.32 ml, $1.83 \mathrm{mmol})$ were added consecutively to a solution of morphine (compound 1) $(0.29 \mathrm{~g}, 1.0 \mathrm{mmol})$ and poly (ethylene glycol) diacid $(0.22 \mathrm{~g}, 1.0 \mathrm{mmol})$ in $\mathrm{DMF}(8 \mathrm{ml})$ at $0^{\circ} \mathrm{C}$ (Fig. 1). The mixture was stirred at room temperature for 4 hours, diluted with $1 \% \mathrm{TFA}$ in water $(10 \mathrm{ml})$ and water $(20 \mathrm{ml})$, and then filtered. The filtrate was loaded to a $220-\mathrm{ml}$ phenyl column $\left(0 \%-14 \% \mathrm{MeCN}\right.$ in $\mathrm{H}_{2} \mathrm{O}+0.1 \%$ TFA). The desired product compound $2(0.25 \mathrm{~g}, 51 \%)$ was obtained as a colorless powder after lyophilization. HRMS (ESI, MicrOTOF), $\mathrm{m} / \mathrm{z}$ calculated for $\mathrm{C}_{25} \mathrm{H}_{31} \mathrm{NO}_{9} 489.1999$, found $490.1976(\mathrm{M}+1)$ (Scheme 1).

Compound 3: TBTU $(0.17 \mathrm{~g}, 0.52 \mathrm{mmol})$ and DIEA $(0.18 \mathrm{ml}, 1.0 \mathrm{mmol})$ were added consecutively to a solution of compound $2(0.25 \mathrm{~g}, 0.51 \mathrm{mmol})$ in $\mathrm{DMF}(6 \mathrm{ml})$ at $0^{\circ} \mathrm{C}$. The mixture was stirred at room temperature for
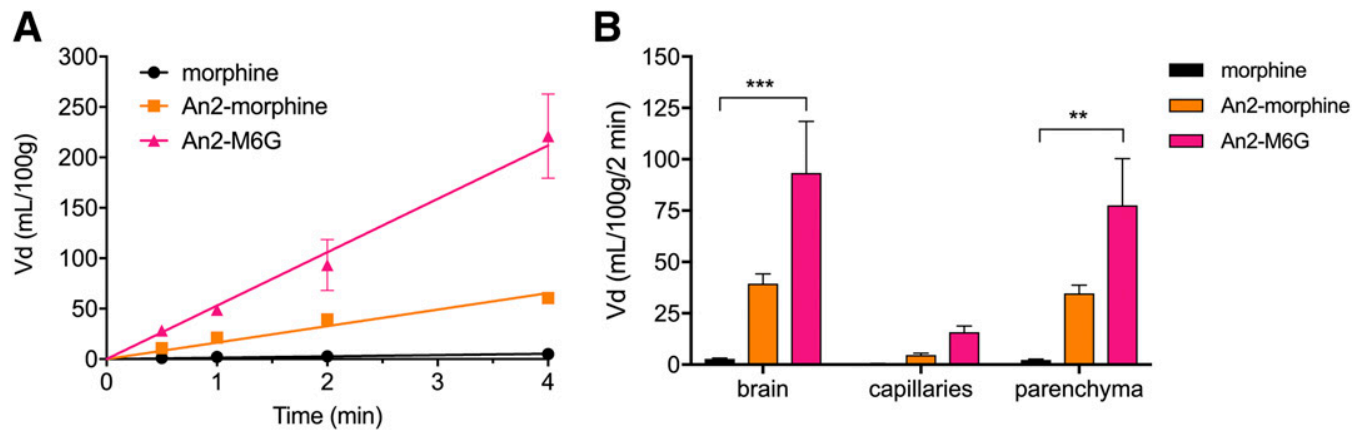

Fig. 1. Brain uptake of radioactive morphine, An2-morphine, and An2-M6G measured by in situ brain perfusion. (A) Time course of brain uptake of $\left[{ }^{3} \mathrm{H}\right]$-morphine, $\left[{ }^{125} \mathrm{I}\right]-$-An2-morphine and $\left[{ }^{125} \mathrm{I}\right]-\mathrm{An} 2-\mathrm{M} 6 \mathrm{G}$. Representation of the $\mathrm{V}_{\mathrm{d}}$ in brain homogenate. (B) Quantification of $\left[{ }^{3} \mathrm{H}\right]-\mathrm{morphine}$, $\left.{ }^{125} \mathrm{I}\right]$-An2-morphine, and $\left[{ }^{125} \mathrm{I}\right]-\mathrm{An} 2-\mathrm{M} 6 \mathrm{G}$ in total brain, capillaries, and parenchymal fractions after 2 minutes of perfusion. Data represent mean \pm S.E.M. $(n=3$ to 4$)$. $* * P<0.01 ; * * * P<0.001$; two-way ANOVA test followed by Tukey's multiple comparison test. 
A<smiles>CN1CC[C@]23O[C@H](C1)c1c(O)ccc(c12)CCN3C</smiles>

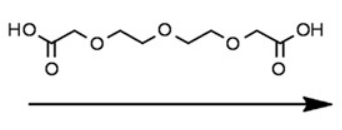

PyBOP, DIEA, DMF, 51\%
$\mathrm{HO}$

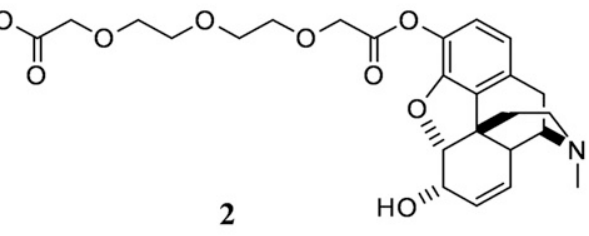

1. TBTU, DIEA, DMF

2. An2, DMSO/DMF, $40 \%$

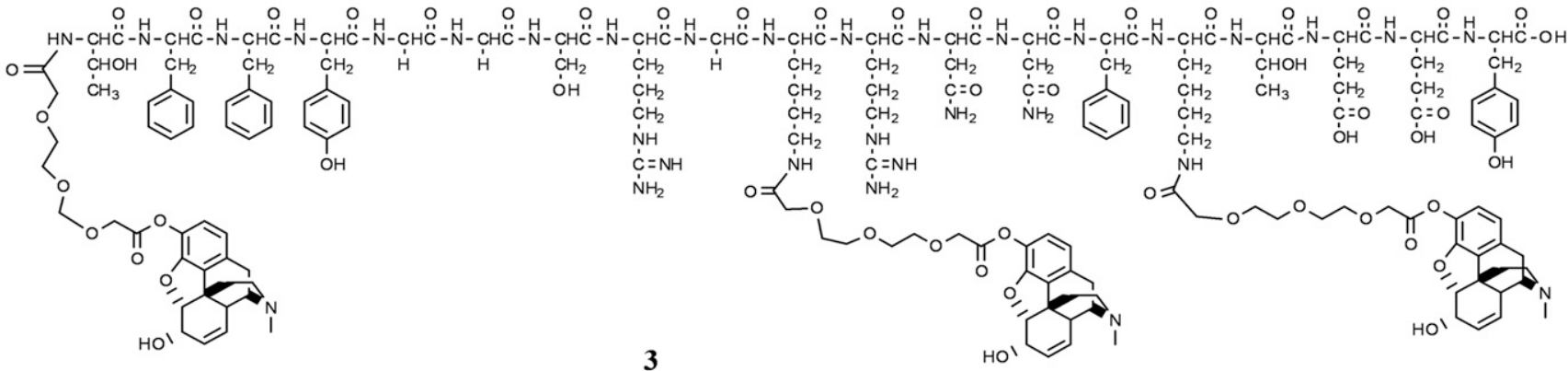

B
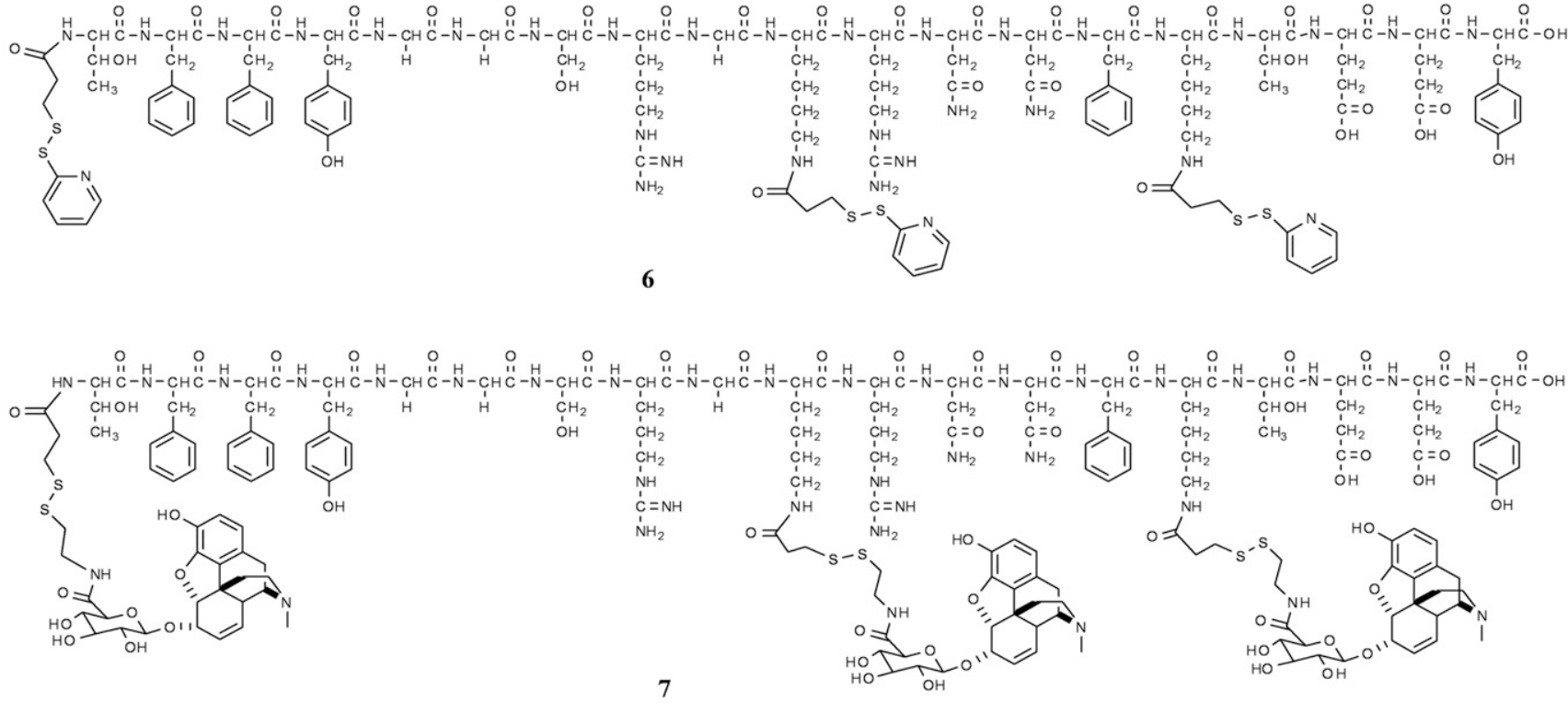

7
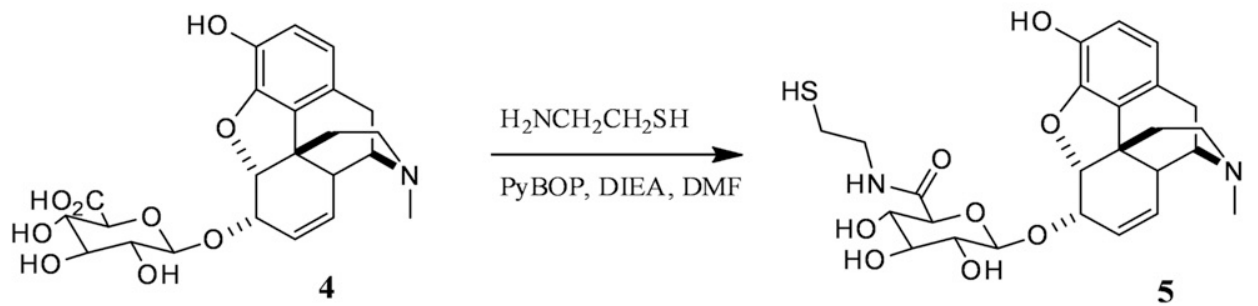

6, $\mathrm{NaHCO}_{3}, \mathrm{DMSO}, \mathrm{DMF}$

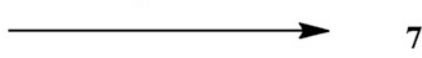

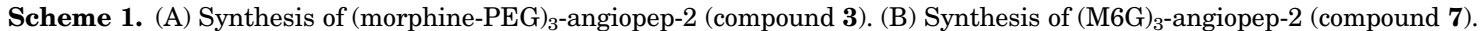


1 hour, and then An2 (0.39 g, $0.17 \mathrm{mmol})$ in DMSO (2 ml) and DMF (2 ml) were added. The mixture was stirred at room temperature for 1 hour. The solution was diluted with $1 \%$ TFA in water $(10 \mathrm{ml})$ and water $(50 \mathrm{ml})$. The crude solution was purified using 220 -ml phenyl column (4\%-32\% MeCN in $\mathrm{H}_{2} \mathrm{O}+0.1 \%$ TFA). The desired product compound $3(251 \mathrm{mg}, 40 \%)$ was obtained as a colorless powder after lyophilization. UPLC purity was $95 \%$.

Compound 5: Benzotriazol-1-yl-oxytripyrrolidinophosphonium hexafluorophosphate $(1.04 \mathrm{~g}, 2.0 \mathrm{mmol})$ and DIEA $(0.63 \mathrm{ml}, 3.62 \mathrm{mmol})$ were added consecutively to a solution of M6G (compound 4) (1.01 g, $1.75 \mathrm{mmol})$ and cystamine $(0.23 \mathrm{~g}, 2.02 \mathrm{mmol})$ in DMF $(15 \mathrm{ml})$ at $0^{\circ} \mathrm{C}$. The mixture was stirred for 30 minutes at $0^{\circ} \mathrm{C}$, diluted with $1 \%$ TFA in water $(10 \mathrm{ml})$ and water $(150 \mathrm{ml})$, and then filtered. The filtrate was loaded to a $220-\mathrm{ml}$ phenyl column (0\%-14\% $\mathrm{MeCN}$ in $\mathrm{H}_{2} \mathrm{O}+0.1 \%$ TFA). The desired product compound $\mathbf{5}(0.8 \mathrm{~g}, 72 \%)$ was obtained as a colorless powder after lyophilization. UPLC purity was $98 \%$. ${ }^{1} \mathrm{HNMR}(300 \mathrm{MHz}$, Methanol- $\left.\mathrm{d}_{4}\right) \delta(\mathrm{ppm}) 8.02(\mathrm{~m}, 1 \mathrm{H}), 6.49(\mathrm{~m}, 2 \mathrm{H}), 5.80(\mathrm{~d}, 1 \mathrm{H}, \mathrm{J}=9.8 \mathrm{~Hz})$, $5.25(\mathrm{~d}, 1 \mathrm{H}, \mathrm{J}=9.7 \mathrm{~Hz}), 5.05(\mathrm{~d}, 1 \mathrm{H}, \mathrm{J}=6.1 \mathrm{~Hz}), 4.57(\mathrm{~d}, 1 \mathrm{H}, \mathrm{J}=7.6 \mathrm{~Hz})$, $4.37(\mathrm{~m}, 1 \mathrm{H}), 4.07(\mathrm{~s}, 1 \mathrm{H}), 3.68(\mathrm{~d}, 1 \mathrm{H}, \mathrm{J}=9.1 \mathrm{~Hz}), 3.50-3.23(\mathrm{~m}, 7 \mathrm{H})$, $3.20-2.75(\mathrm{~m}, 6 \mathrm{H}), 2.52(\mathrm{t}, 2 \mathrm{H}, \mathrm{J}=6.8 \mathrm{~Hz}), 2.22(\mathrm{~m}, 1 \mathrm{H}), 2.0(\mathrm{~m}, 1 \mathrm{H})$; ${ }^{13} \mathrm{C}$ NMR (75 MHz, Methanol-d $\left.{ }_{4}\right) \delta(\mathrm{ppm}) 175.75,147.55,141.85$, 134.07, 130.10, 126.17, 123.61, 121.16, 118.80, 103.47, 89.33, 77.47, 76.50, 74.88, 73.80, 73.47, 62.44, 43.54, 43.10, 40.50, 35.26, 24.40. HRMS (ESI, MicrOTOF), m/z calculated for $\mathrm{C}_{25} \mathrm{H}_{32} \mathrm{~N}_{2} \mathrm{O}_{8} \mathrm{~S} 520.1879$, found $521.1835(\mathrm{M}+1)$.

Compound 6: $N$-succinimidyl-3-(2-pyridyldithio)propionate $(0.8 \mathrm{~g}$, $2.55 \mathrm{mmol})$ and DIEA $(0.44 \mathrm{ml}, 2.55 \mathrm{mmol})$ were added consecutively to a solution of An2 (compound 3 ) $(1.88 \mathrm{~g}, 0.64 \mathrm{mmol})$ in DMSO $(2.5 \mathrm{ml})$ and DMF $(6 \mathrm{ml})$. The mixture was stirred at room temperature for 2 hours and diluted with $0.1 \%$ TFA in water $(20 \mathrm{ml})$ and water $(50 \mathrm{ml})$. The crude solution was purified using 220 -ml phenyl column (15\%$60 \% \mathrm{MeCN}$ in $\mathrm{H}_{2} \mathrm{O}+0.1 \%$ formic acid). The desired product compound $6(1.11 \mathrm{~g}, 60 \%)$ was obtained as a colorless powder after lyophilization. UPLC purity was $95 \%$. LC-HRMS (ESI, micrOTOF), $\mathrm{m} / \mathrm{z}$, calculated for $\mathrm{C}_{128} \mathrm{H}_{170} \mathrm{~N}_{32} \mathrm{O}_{34} \mathrm{~S}_{6} 2892.0915$, found 1447.5050 (2+), 965.3478 (3+), and 724.0177 (4+).

Compound 7: A mixture of compound 5 (0.5 g, $0.79 \mathrm{mmol})$, compound 6 (0.63 g, $0.22 \mathrm{mmol})$, and $\mathrm{NaHCO}_{3}(94 \mathrm{mg}, 1.08 \mathrm{mmol})$ in DMSO $(10 \mathrm{ml})$ was stirred at room temperature for 30 minutes. The solution was cooled to $0^{\circ} \mathrm{C}$ and diluted with $1 \%$ TFA in water $(10 \mathrm{ml})$ and water $(80 \mathrm{ml})$. The crude solution was purified using $220-\mathrm{ml}$ phenyl column (4\%-32\% $\mathrm{MeCN}$ in $\mathrm{H}_{2} \mathrm{O}+0.1 \%$ TFA). The desired product compound $7(630 \mathrm{mg}, 70 \%)$ was obtained as a colorless powder after lyophilization. UPLC purity was 95\%. LC-HRMS (ESI, micrOTOF), m/z, calculated for $\mathrm{C}_{188} \mathrm{H}_{251} \mathrm{~N}_{35} \mathrm{O}_{58} \mathrm{~S}_{6} 4120.6159$, found $2061.7995(2+), 1374.5352(3+)$, and $1031.1606(4+)$.

Animals. Adult male Crl:CD-1 or C57BL/6 mice or adult male Sprague-Dawley rats (225-250 g; 12-hour light/12-hour dark cycle; Charles River Laboratories, St-Constant, QC, Canada) were allowed ad libitum access to food and water. Rodents were acclimatized for 1 day to manipulations and devices prior to the behavioral studies, which were performed in a quiet room by the same experimenter between 8:00 AM and 12:00 AM. The experimental procedures in this study were approved by the Animal Care Committee of the University of Sherbrooke and were in accordance with policies and directives of the Canadian Council on Animal Care and adhere to the Animal Research: Reporting of In Vivo Experiments guidelines.

Brain Uptake. Transcytosis of $\left[{ }^{125} \mathrm{I}\right]$-An2-morphine and $\left[{ }^{125} \mathrm{I}\right]$ An2-M6G into the brain was performed on adult male mice using the brain perfusion method and compared with $\left[{ }^{3} \mathrm{H}\right]$-morphine (Dagenais et al., 2000). Radiolabeled molecules were solubilized in a Krebs/bicarbonate buffer (128 mM NaCl, $24 \mathrm{mM} \mathrm{NaHCO}$, $4.2 \mathrm{mM} \mathrm{KCl}, 2.4 \mathrm{mM} \mathrm{NaH}{ }_{2} \mathrm{PO}_{4}, 1.5 \mathrm{mM} \mathrm{CaCl}_{2}, 0.9 \mathrm{mM} \mathrm{MgCl}_{2}$, and $9 \mathrm{mM} D$-glucose; gassed with $95 \% \mathrm{O}_{2}$ and $5 \% \mathrm{CO}_{2}, \mathrm{pH} 7.4,37^{\circ} \mathrm{C}$ ) and loaded on the infusion pump (Harvard pump PHD 2000; Harvard Apparatus) connected to a catheter inserted beforehand into the right carotid as previously described (Demeule et al., 2014). The radiolabeled compounds at $1 \mu \mathrm{M}$ were perfused into the carotid under 5 minutes for the time course brain uptake or
2 minutes for the quantification in separate fractions at a flow rate of $2.5 \mathrm{ml} / \mathrm{min}$, which was followed by a 30 -second Krebs' buffer perfusion. Right brain hemisphere was then quickly isolated on ice after mice euthanasia, and this was followed by various purification steps, as described precisely by Demeule et al. (2014). Samples were placed in 5-ml glass tubes, and the radioactivity was determined using a Wizard ${ }^{2}$ Automatic Gamma Counter. Total brain homogenate data are represented as apparent distribution volume $\left(\mathrm{V}_{\mathrm{d}}\right)$ by a least-squares regression.

For capillary depletion, the mouse brain was homogenized on ice in Ringer's HEPES buffer with $0.1 \%$ bovine serum albumin in a glass homogenizer. Brain homogenate was then mixed thoroughly with $35 \%$ Dextran 70 (50:50) and centrifuged at 5400g for 10 minutes at $4^{\circ} \mathrm{C}$. The supernatant (brain parenchyma) and the pellet (capillaries) were separated. Aliquots of homogenates, supernatants, pellets, and perfusates were collected at every step to determine the concentration of each radiolabeled compound necessary for the calculation of the apparent $V_{d}$ in the different brain fractions. Data are expressed as the mean \pm S.E.M. $(n=4)$ and were analyzed using GraphPad Prism 7.0.

Acute Pain Models. The antinociceptive effects of morphine, M6G, An2-morphine, and An2-M6G have been assessed using different pain modalities, including hot-plate and heat tail-flick immersion tests. In the hot-plate assay, male CD1 mice (25-30 g) were placed onto a metal plate heated at $54^{\circ} \mathrm{C}$ surrounded by a Plexiglas cylinder $(\mathrm{d} \times \mathrm{h}: 13 \times 19 \mathrm{~cm})$. Baseline readings were done for each mouse immediately prior to drug injection. Animal latency to the first foot lick was recorded (maximum 30 seconds, to prevent tissue damage). The analgesic potencies of morphine, M6G, An2-morphine, and An2M6G were also evaluated in adult male Sprague-Dawley rats using the tail-flick test. This acute pain test consists of measuring the time taken to flick or withdraw the tail from the heat after immersion of $5 \mathrm{~cm}$ of the tail in a hot water bath $\left(53 \pm 0.5^{\circ} \mathrm{C}\right)$. Before administrating the compounds, baselines were measured three times within 30 minutes. Rats were then tested every 15-30 minutes up to 6 hours after drug administration (intravenously or subcutaneously). A cutoff of 10 seconds was imposed for the duration of the test to avoid tissue damage. Hot-plate and tail-flick latencies were used to determine the percentage of the maximum possible effect (MPE) calculated as $\% \mathrm{MPE}=100 \times($ time to tail withdrawal - baseline $) /($ cutoff - baseline $)$. The area under the curve (AUC) was also determined to evaluate the total antinociceptive effect of each compound.

Charcoal Meal Test. Constipation has been assessed by measuring the gastrointestinal tract motility using the charcoal meal test. Food-deprived (16 hours) rats were injected subcutaneously with saline, morphine, M6G, An2-morphine, or An2-M6G. Thirty minutes after drug injection, $2 \mathrm{ml}$ of a charcoal meal solution (5\% arabic gum and $10 \%$ charcoal in water) was administered to the rats by gavage. The animals were euthanized exactly 60 minutes after drug injection, and the progression of the charcoal in the intestine was measured as a ratio of progression/total length of the intestine. The results are presented as a percentage of progression of the charcoal meal in the intestine.

Statistical Analysis. Two-way ANOVA and Tukey's multiple comparison post hoc test were used to compare the brain uptake of radiolabeled compounds. Data of hot-plate and tail-flick experiments were compared using one-way ANOVA test followed by either Dunnett's or Tukey's multiple comparison test. Data of gastrointestinal tract motility experiments were compared using the Kruskal-Wallis nonparametric test followed by Dunn's multiple comparison test. Statistical analyses were performed using GraphPad Prism (version 7.00; GraphPad Software Inc.).

\section{Results}

In Vivo Brain Penetration. Morphine and M6G were first conjugated to An2, a 19-mer peptide that crosses the BBB by low-density lipoprotein receptor-related protein 1 (LRP1) 
TABLE 1

In vivo brain uptake of the compounds expressed in influx rate constant $\left(\mathrm{K}_{\text {in }}\right)$

\begin{tabular}{llc}
\hline \multirow{2}{*}{ Compounds } & \multicolumn{2}{c}{ Brain $\mathrm{K}_{\text {in }}(\mathrm{ml} / \mathrm{s}$ per gram $)$} \\
\cline { 2 - 3 } & Experimental & Theoretical $^{a}$ \\
\hline Glucose & $2.2 \times 10^{-4}$ & $9.5 \times 10^{-3}$ \\
Morphine & $2.7 \times 10^{-3}$ & \\
An2-morphine & $8.8 \times 10^{-3}$ & $2 \times 10^{-5}$ \\
M6G & \\
An2-M6G & \\
\hline
\end{tabular}

${ }^{a}$ The M6G and glucose values used are from Wu et al. (1997).

receptor-mediated transcytosis. As described in the Materials and Methods section (Scheme 1), the new chemical entities carried three molecules of morphine or M6G per An2. The resulting new drug conjugates were then evaluated for their ability to penetrate the BBB (Fig. 1). Transcytosis of $\left[{ }^{125} \mathrm{I}\right]$-An2-morphine, $\left[{ }^{125} \mathrm{I}\right]-\mathrm{An} 2-\mathrm{M} 6 \mathrm{G}$, and $\left[{ }^{3} \mathrm{H}\right]$-morphine over time was determined by in situ brain perfusion after intravenous drug administration. As opposed to morphine (4.9 \pm $2.7 \mathrm{ml} / 100 \mathrm{~g}$ of brain), the $\mathrm{V}_{\mathrm{d}}$ of $\left[{ }^{125} \mathrm{~T}\right]$-An2-morphine and $\left[{ }^{[25} \mathrm{I}\right]-$ An2-M6G found in total brain homogenates increased linearly over time to reach, respectively, $60.6 \pm 33 \mathrm{ml} / 100 \mathrm{~g}$ of brain and $221.1 \pm 98 \mathrm{ml} / 100 \mathrm{~g}$ of brain after 4 minutes (Fig. 1A). The BBB influx rate constants $\left(\mathrm{K}_{i n}\right)$ of each compound corresponding to the slope of the curves in Fig. 1A are shown in Table 1. The $K_{i n}$ for the conjugate An2-morphine was found to be 12-fold higher $\left(2.7 \times 10^{-3} \mathrm{ml} / \mathrm{s}\right.$ per gram $)$ than that of the unconjugated morphine $\left(2.2 \times 10^{-4} \mathrm{ml} / \mathrm{s}\right.$ per gram $)$. Likewise, the conjugation of M6G to An2 improved its influx rate from blood to brain by more than 440 -fold $\left(8.8 \times 10^{-3} \mathrm{ml} / \mathrm{s}\right.$ per gram compared with the theoretical value of M6G, which is $2 \times 10^{-5} \mathrm{ml} / \mathrm{s}$ per gram)
(Wu et al., 1997). The $\mathrm{K}_{\text {in }}$ of An2-M6G was indeed similar to that of glucose $\left(9.5 \times 10^{-3} \mathrm{ml} / \mathrm{s}\right.$ per gram $)$, which was used as a positive control for brain permeability (Wu et al., 1997).

To confirm penetration of the compounds in the parenchyma compartment, a depletion of brain capillaries was then performed. We estimated apparent $\mathrm{V}_{\mathrm{d}}$ of An2-morphine and An2-M6G after 2 minutes of perfusion in the total brain tissue, capillaries, and parenchymal fraction (Fig. 1B). When compared with morphine, An2-morphine had a significantly higher $\mathrm{V}_{\mathrm{d}}$ in the brain and parenchymal fractions. Likewise, An2-M6G was mainly found within the brain parenchyma. Overall $80 \%-90 \%$ of An2-morphine and An2-M6G was associated with the parenchymal fraction, and only 10\%-20\% remained trapped within the brain vasculature. These results demonstrate that both An2-morphine and An2-M6G were able to cross the BBB more efficiently than unconjugated opioids.

Antinociceptive Effects of An2-Morphine and An2-M6G after Intravenous Administration. Using the rat tail-flick test, we evaluated the antinociceptive effects of morphine, M6G, An2-morphine, and An2-M6G after systemic delivery. Morphine and An2-morphine induced a dose- and timedependent increase in the time reaction to tail withdrawal (Fig. 2). Our results show that the administration of morphine $(0.3-3 \mathrm{mg} / \mathrm{kg}$, i.v.) produced a maximal antinociceptive effect (\%MPE) of $88.6 \%$ at the highest dose tested (Fig. 2, A-C). When equimolar doses of morphine conjugated to An2 (An2morphine; $3 \mathrm{mg} / \mathrm{kg}$ ) were compared with unconjugated morphine $(1 \mathrm{mg} / \mathrm{kg})$ at the peak effect, similar levels of antinociception were observed, reaching $46 \%$ and $49.7 \%$ of $\mathrm{MPE}$, respectively (Fig. 2, B and E).

The analgesic effects of intravenous M6G and An2-M6G were also evaluated in the rat tail-flick assay (Fig. 3). These two compounds also produced a time- and dose-dependent
A
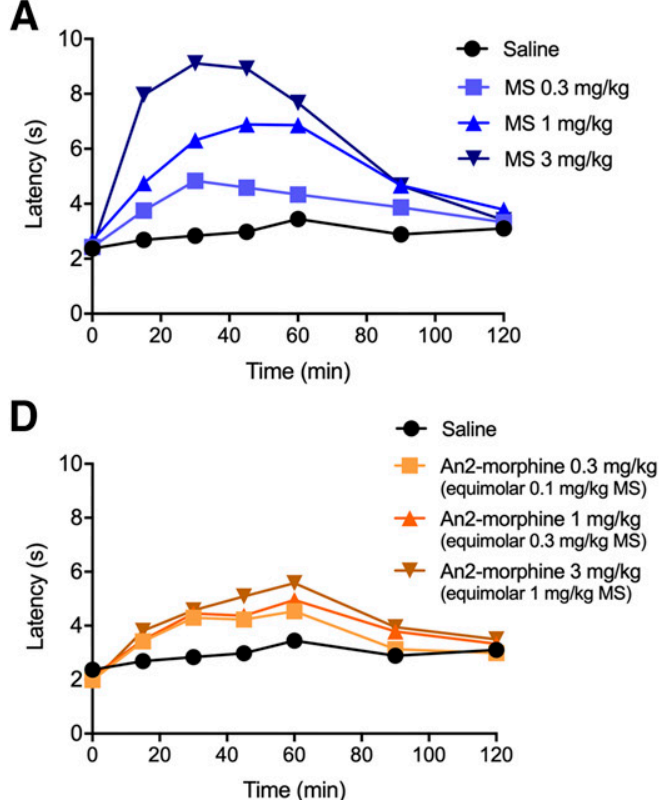

B

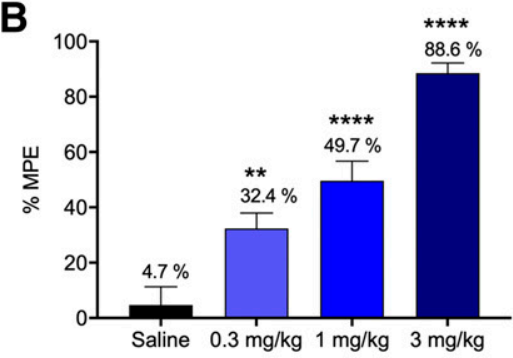

$E$

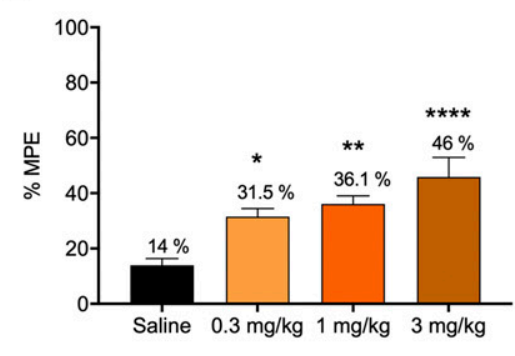

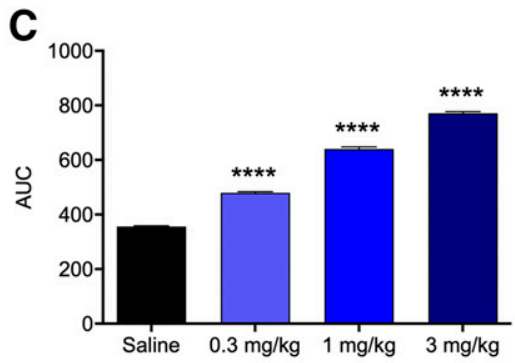

$\mathbf{F}$

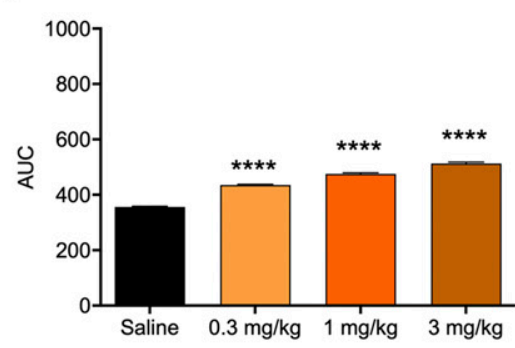

Fig. 2. Antinociceptive effects of intravenous morphine and An2-morphine in the tail-flick assay. The antinociceptive effects of morphine and An2-morphine were evaluated by measuring the time to tail withdrawal in the tail-flick assay. Rats were treated intravenously with saline or with increasing doses of either morphine sulfate (MS) $[0.3 \mathrm{mg} / \mathrm{kg}(n=10), 1 \mathrm{mg} / \mathrm{kg}(n=7)$, and $3 \mathrm{mg} / \mathrm{kg}(n=10)]$ (A) or An2-morphine [0.3 mg/kg $(n=10), 1 \mathrm{mg} / \mathrm{kg}(n=10)$, and $3 \mathrm{mg} / \mathrm{kg}(n=9)]$ (D). For each dose, the \%MPE was calculated for morphine and An2-morphine, as shown in (B and $\mathrm{E})$, respectively. The AUC representing the total drug exposure across time (i.e., 120 minutes) after administration of increasing doses of MS is represented in (C), whereas the AUC of equimolar doses of An2-morphine is shown in (F). $* P<0.05 ; * * P<0.01 ; * * * P<0.0001$ compared with the saline group; one-way ANOVA followed by Dunnett's multiple comparisons test. 
A

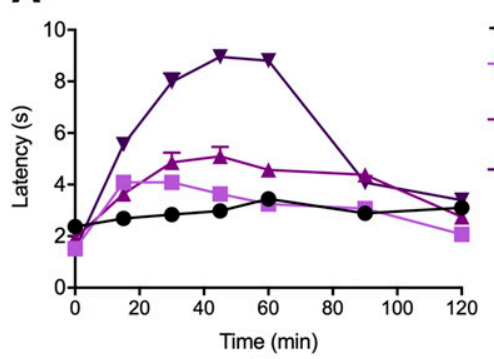

D

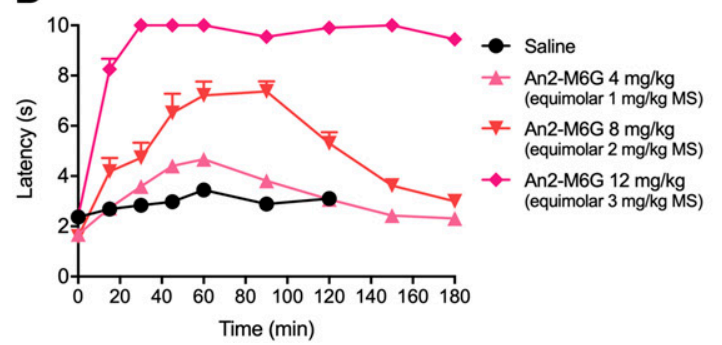

B

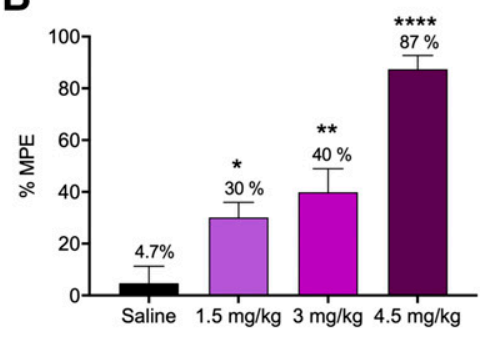

E

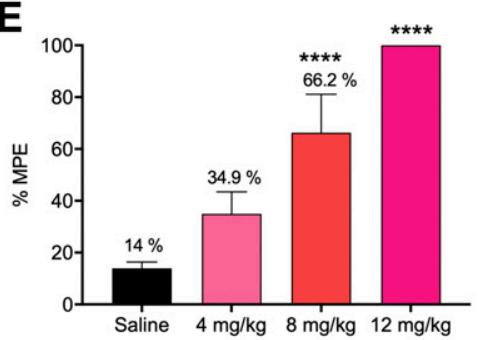

C

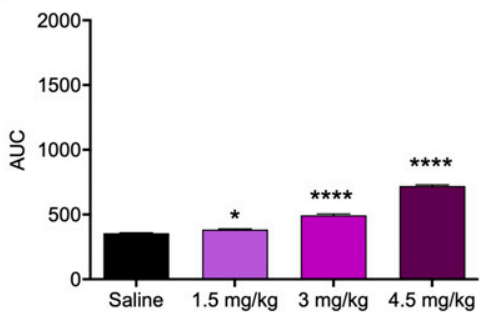

F

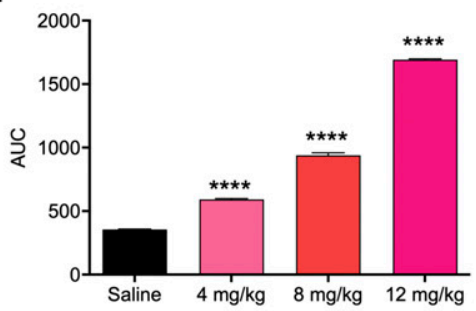

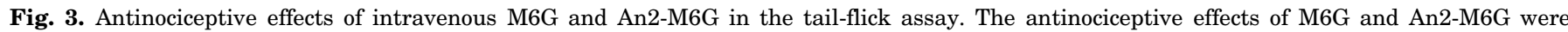

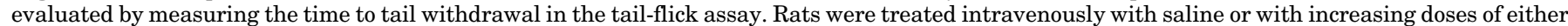

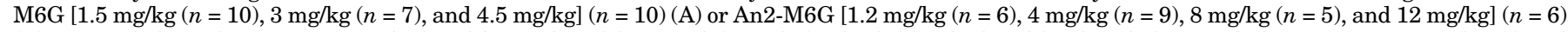

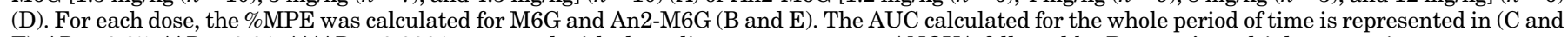
F). ${ }^{*} P<0.05$; ${ }^{*} P<0.01$; $* * * * P<0.0001$ compared with the saline group; one-way ANOVA followed by Dunnett's multiple comparisons test.

antinociception. The intravenous injection of $1.5-4.5 \mathrm{mg} / \mathrm{kg}$ M6G induced a \% MPE ranging from $30 \%$ to $87 \%$ (Fig. 3, A-C). Most interestingly, An2-M6G induced a long-lasting, robust, dose-dependent antinociceptive effect. Indeed, at an equimolar dose of $3 \mathrm{mg} / \mathrm{kg}$ of morphine (i.e., $12 \mathrm{mg} / \mathrm{kg}$ ), An2-M6G produced a latency to tail withdrawal reaching the cutoff (i.e., 10 seconds) after 30 minutes, an effect lasting at least 3 hours (Fig. 3, D-F). The \%MPE calculated at 60 minutes after the intravenous injection of An2-M6G at 4, 8, and $12 \mathrm{mg} / \mathrm{kg}$ (equivalent to 1, 2, and $3 \mathrm{mg} / \mathrm{kg}$ of morphine and to $1.5,3$, and $4.5 \mathrm{mg} / \mathrm{kg}$ of M6G) was $34.9 \%, 66.2 \%$, and $100 \%$, respectively (Fig. 3E).

Similar results were also obtained in the hot-plate test using male CD1 mice (Fig. 4). Over a 2-hour period, both morphine and An2-morphine caused similar increases in hot-plate latencies (Fig. 4, A-C). Likewise, mice receiving An2-M6G (6 mg/kg i.v.) also exhibited a sustained and superior analgesic effect compared with equimolar doses of either morphine or M6G (Fig. 4, D-F).

Antinociceptive Effects Produced by the Subcutaneous Administration of An2-Morphine and An2-M6G. We also measured the analgesic effect of An2-morphine and An2-M6G after subcutaneous injections (Fig. 5). Despite similar MPE at the peak effect, subcutaneous injection of $20 \mathrm{mg} / \mathrm{kg}$ An2-morphine (equivalent to $5.5 \mathrm{mg} / \mathrm{kg}$ of morphine) produced an analgesic effect that was more prolonged over the time than what was observed with an equimolar dose of morphine (Fig. 5, A and B). Indeed, when the AUC was calculated for each compound, we found that the level of antinociception induced by An2-morphine over the course of 120 minutes was significantly higher than that of morphine (Fig. 5C). The antinociceptive effects of s.c. $12 \mathrm{mg} / \mathrm{kg}$ An2-M6G (representing an equimolar dose of $4.5 \mathrm{mg} / \mathrm{kg} \mathrm{M} 6 \mathrm{G}$ or $3 \mathrm{mg} / \mathrm{kg}$ morphine) were also determined (Fig. 5, D-F). The duration of antinociception was different for each of the compounds. Indeed, the antinociceptive effects of $3 \mathrm{mg} / \mathrm{kg}$ morphine returned to baseline after 90 minutes, whereas the antinociceptive effects of $4.5 \mathrm{mg} / \mathrm{kg} \mathrm{M} 6 \mathrm{G}$ returned to baseline only after 180 minutes. Most interestingly, the antinociceptive properties of the An2-M6G conjugate were maintained for over 380 minutes (Fig. 5D). The AUC was calculated for each compound and included only the first 180 minutes after the injections (Fig. 5D). The AUC for M6G and An2-M6G was found to be significantly higher than both saline and morphine groups. Furthermore, the antinociception produced by An2-M6G was significantly higher than that of an equimolar dose of M6G (Fig. 5F).

Modulation of the Gastrointestinal Tract Motility. To evaluate whether An2-morphine and An2-M6G produced constipation, one of the main adverse effects of opioids, the effects of An2-morphine at $20 \mathrm{mg} / \mathrm{kg}$ (equimolar to $5.5 \mathrm{mg} / \mathrm{kg}$ of morphine) and An2-M6G at 4 and $20 \mathrm{mg} / \mathrm{kg}$ (respectively, equimolar to 1 and $5 \mathrm{mg} / \mathrm{kg}$ of morphine) were measured and compared with morphine at 1,5 , and $10 \mathrm{mg} / \mathrm{kg}$. As reported in Table 2, subcutaneous administration of morphine produced a dosedependent decrease of the charcoal meal progression in the intestine of $58.0 \% \pm 2.7 \%, 49.7 \% \pm 2.7 \%$, and $28.6 \% \pm 3.7 \%$ at 1 , 5 , and $10 \mathrm{mg} / \mathrm{kg}$ of morphine, respectively, as compared with $73.4 \% \pm 2.2 \%$ in the saline-treated group. An2-morphine at $20 \mathrm{mg} / \mathrm{kg}$ induced a similar decrease as morphine at an equimolar dose with a progression of $45.1 \% \pm 5.1 \%$. Interestingly, the An2-M6G doses did not produce a significant decrease of the gastrointestinal tract motility when compared with the saline group. A dose of $4 \mathrm{mg} / \mathrm{kg}$ induced $61.5 \% \pm 3.3 \%$ of charcoal meal progression, and $20 \mathrm{mg} / \mathrm{kg}$ induced $59.7 \% \pm 3.1 \%$ (respectively, equimolar to 1 and $5 \mathrm{mg} / \mathrm{kg}$ of morphine), suggesting that in addition to its higher antinociceptive action, An2-M6G produced minimal effects on the gastrointestinal tract motility.

\section{Discussion}

Despite its important adverse effects, morphine remains one of the most commonly used analgesics for the treatment of 


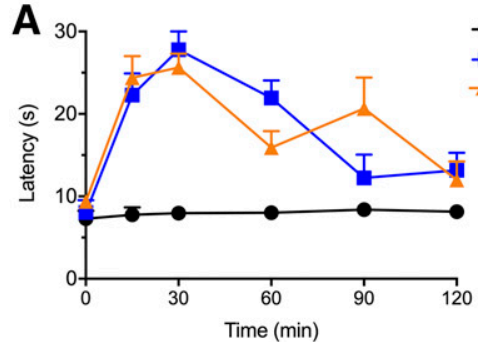

D

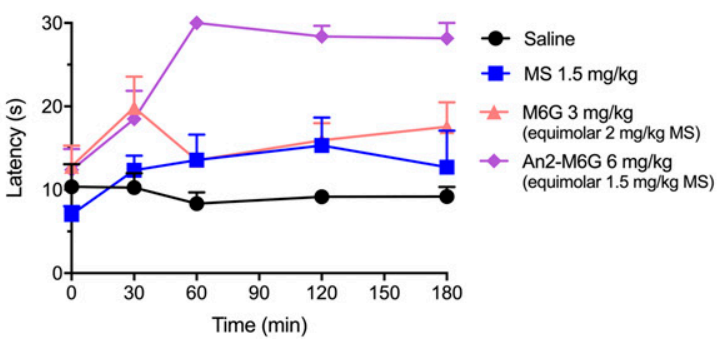

B

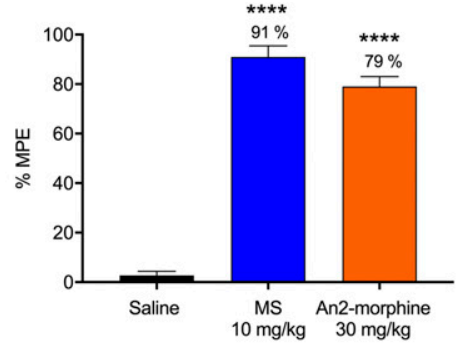

E

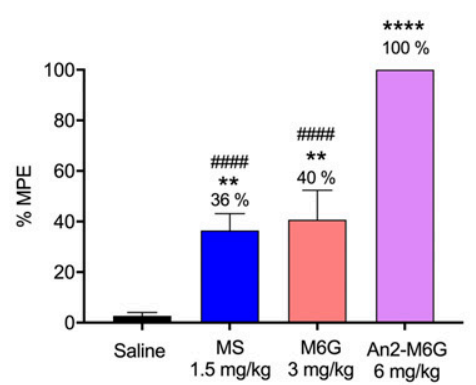

C

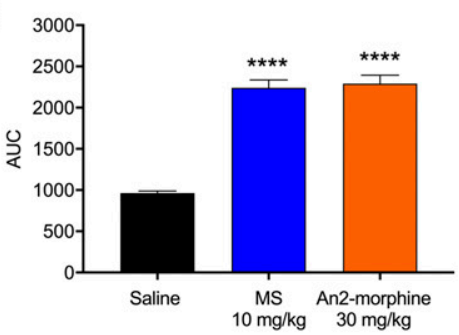

F

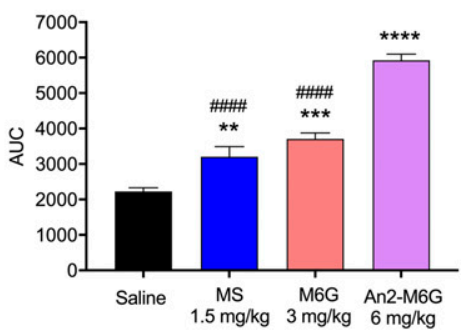

Fig. 4. Antinociceptive effects of intravenous morphine, An2-morphine, morphine-6-glucuronide, and An2-M6G in the hot-plate test. The antinociceptive effects of morphine sulfate (MS), An2-morphine, M6G, and An2-M6G were evaluated by measuring the paw-licking behaviors of adult male CD1 mice in the thermal hot-plate assay. Mice were injected intravenously with saline, $10 \mathrm{mg} / \mathrm{kg}$ of MS or $30 \mathrm{mg} / \mathrm{kg}$ of An2-morphine (A) or saline, $1.5 \mathrm{mg} / \mathrm{kg}$ of morphine, $3 \mathrm{mg} / \mathrm{kg}$ of M6G, and $6 \mathrm{mg} / \mathrm{kg}$ of An2-M6G ( $n=5$ per group) (D). For each drug, the \%MPE was calculated, as shown in (B and E). The AUC after administration of equimolar doses of MS and An2-morphine is represented in (C), whereas the AUC of equimolar doses of MS, M6G, and An2-M6G are shown in $(\mathrm{F}) .{ }^{* *} P<0.01 ;{ }^{* * *} P<0.001 ;{ }^{* * * *} P<0.0001$ compared with saline group; ${ }^{\#} P<0.05$; ${ }^{\# \# \# \#} P<0.0001$ compared with An2-M6G; one-way ANOVA test followed by Tukey's multiple comparison test.

moderate to severe pain (Balch and Trescot, 2010). Among all adverse effects produced by morphine, constipation is often the most debilitating for patients. Importantly, constipation is not significantly subject to tolerance and is therefore amplified as the doses escalate to compensate for analgesic tolerance. Although the analgesic effects of opioids are mainly mediated by central receptors, constipation is due to a direct action on the gastrointestinal tract (Holzer, 2009). However, the ability of morphine to cross the BBB is limited, and it is estimated that only about $0.02 \%$ of the total amount of morphine reaches the brain after systemic administration (Oldendorf et al., 1972; Banks and Kastin, 1994). Because of this poor BBB
A

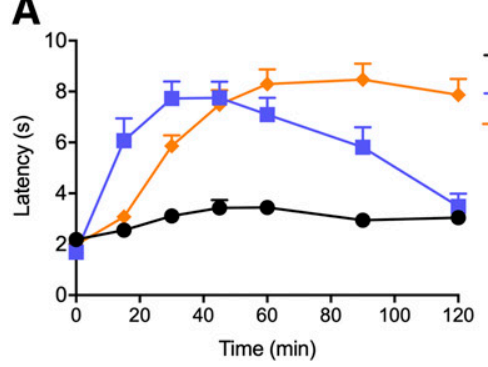

D

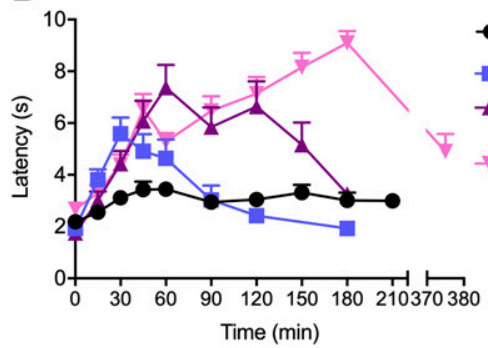

B

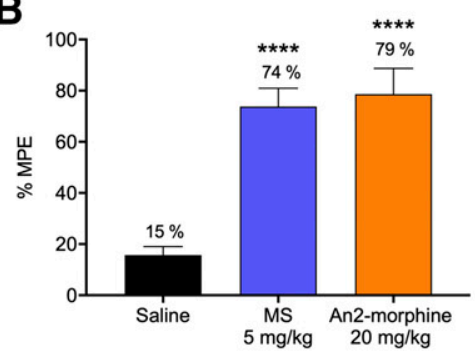

E

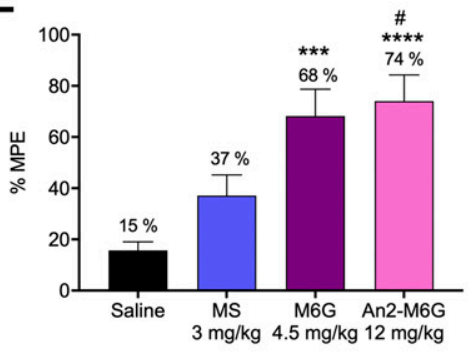

C

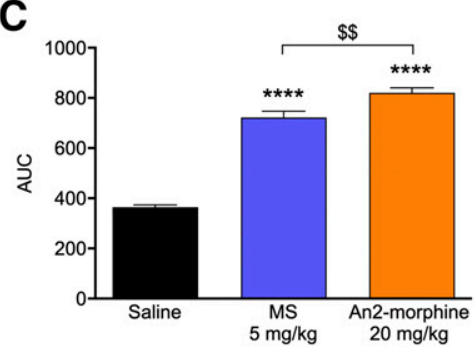

$\mathbf{F}$

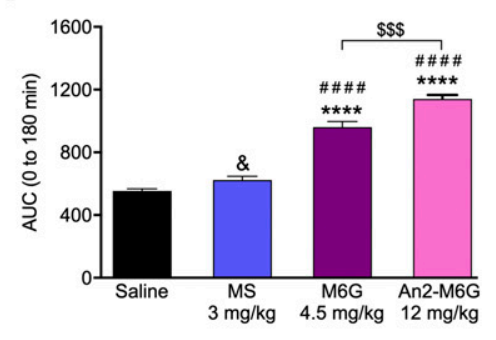

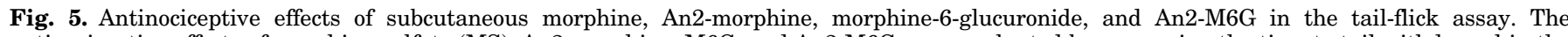

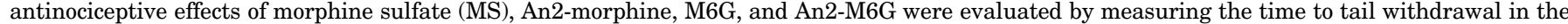

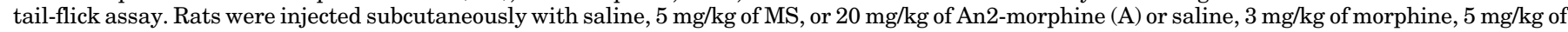

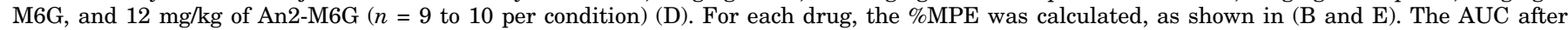

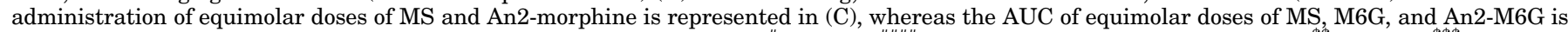

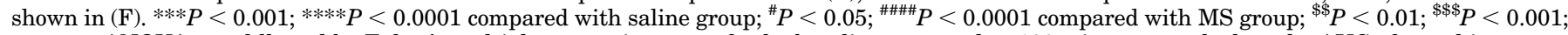

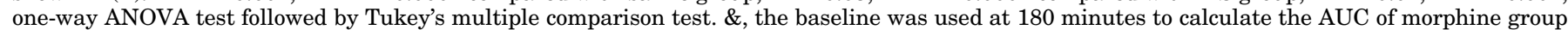
until 180 minutes. 
TABLE 2

Effect of morphine, An2-M6G, and An2-morphine on the gastrointestinal tract motility

Saline, MS (1, 5 and $10 \mathrm{mg} / \mathrm{kg})$, An2-M6G (4 and $20 \mathrm{mg} / \mathrm{kg})$, and An2-morphine $(20 \mathrm{mg} / \mathrm{kg}$ ) were injected subcutaneously 30 min before force-feeding with a charcoal meal solution. The progression of the charcoal meal in the intestine was measured $1 \mathrm{~h}$ after force-feeding.

\begin{tabular}{|c|c|c|c|c|c|c|c|}
\hline Treatment & Saline & & Morphine Sulfate & & & M6G & An2-morphine \\
\hline$n$ & 10 & 10 & 10 & 10 & 10 & 10 & 10 \\
\hline Dose $(\mathrm{mg} / \mathrm{kg})$ & & 1 & 5 & 10 & 4 & 20 & 20 \\
\hline Equimolar MS & & & & & 1 & 5 & 5.5 \\
\hline
\end{tabular}

MS, morphine sulfate.

${ }^{*} P<0.05$, ${ }^{* * *} P<0.001$, and $* * * * P<0.0001$ compared with saline group; ${ }^{\$} P<0.05$ An2-M6G (20 mg/kg) compared with An2-morphine (20 mg/kg); Kruskal-Wallis nonparametric test followed by Dunn's multiple comparison test.

permeability, high doses of morphine are needed to produce analgesia, thus increasing the adverse effects (Oldendorf et al., 1972; Koyyalagunta, 2007). The second main problem of morphine therapy is the high interindividual variability in serum concentrations of morphine and its metabolites M6G and M3G among patients (Klepstad et al., 2003). Indeed, the level of glucuronidation of morphine in M6G and M3G by the glucuronosyltransferase enzyme, UGT2B7, can significantly impact the amplitude of morphine antinociception (Yang et al., 2017). Accordingly, it has been reported in daily clinical practices that patients with diverse UGT2B7 gene polymorphisms have a different analgesic response to the same dose of morphine (Bastami et al., 2014).

In this study, we created new brain-penetrating peptidedrug conjugates to increase the BBB permeability of morphine and its highly potent metabolite M6G. We hypothesized that such an approach could ameliorate the therapeutic profiles of morphine and M6G by increasing their brain distribution and thereby reduce the dose required to produce analgesia. Here, we conjugated morphine and M6G to the brain penetrant 19mer peptide An2. The An2 peptide was previously shown to efficiently bind to the LRP1 present at the luminal endothelial cells of brain capillaries (Demeule et al., 2008). Using LRP1 receptors, the An2-drug complex can therefore cross the $\mathrm{BBB}$ via a receptor-mediated transcytosis mechanism (Demeule et al., 2008; Bertrand et al., 2010). This approach was successfully applied to improve brain uptake of peptides like neurotensin or anticancer agents, such as paclitaxel, doxorubicin, or etoposide (Demeule et al., 2008, 2014; Régina et al., 2008; Thomas et al., 2009; Bertrand et al., 2011; Eiselt et al., 2019). To achieve optimal brain concentrations of morphine and $\mathrm{M} 6 \mathrm{G}$, these opioid drugs were conjugated with a ratio of 3 to 1 to the An2 peptide. As expected, such a coupling strategy produced a significant increase in the parenchymal uptake of morphine and M6G. It was previously shown that the brain penetration of M6G is more than 30-50-fold lower than that of morphine (Bickel et al., 1996; Wu et al., 1997). However, when coupled to An2, the brain penetration of M6G injected intravenously was 3-fold and 40-fold higher than that of An2-morphine and nonconjugated morphine, respectively. The level of BBB permeability of An2-M6G can indeed be compared with the permeability of glucose (McAllister et al., 2001).

According to the literature, M6G is a strong $\mu$ opioid receptor agonist with even higher affinity than morphine itself (Chen et al., 1991). Importantly, previous studies revealed that about $96.6 \%, 85.6 \%$, and $85.4 \%$ of the analgesic effect of oral, subcutaneous, and intravenous administrations of morphine is caused by M6G (Klimas and Mikus, 2014). Although the coupling of morphine to An2 had no major effects on its antinociceptive properties after its intravenous administration, its subcutaneous delivery was found to produce a delayed but prolonged antinociception, up to 2 hours, compared with equimolar dose of unconjugated morphine. As previously shown, despite a low brain penetration, we observed that intravenous or subcutaneous M6G produced a dose- and time-dependent antinociceptive effect in the rat tail-flick assay similar to that of morphine (Paul et al., 1989). Our results further demonstrated that the An2-M6G conjugate was notably more potent than unconjugated M6G, with all animals reaching the cutoff 30 minutes after intravenous injection of $12 \mathrm{mg} / \mathrm{kg}$ An2-M6G (which is equivalent to $3 \mathrm{mg} / \mathrm{kg}$ of morphine and to $4.5 \mathrm{mg} / \mathrm{kg}$ of M6G). More importantly, intravenous An2-M6G also has a longer duration of action when compared with equimolar doses of morphine and M6G. Indeed, the antinociceptive effect of $12 \mathrm{mg} / \mathrm{kg}$ of An2-M6G remained maximal after 3 hours, whereas the latency to tail withdrawal was back to the baseline 120 minutes after intravenous injection of either morphine or M6G. Similarly, the analgesic profile of intravenous An2-M6G was superior to that of M6G and morphine in CD1 mice submitted to the hot-plate test. Finally, subcutaneous delivery of An2-M6G produced long-lasting analgesia with greater potency and efficacy than unconjugated M6G and morphine. These observations support the hypothesis that a significantly higher level of M6G penetrates into the brain when conjugated to An2 and highlights the potential use of lower doses of opioids to provide effective antinociception. Accordingly, brain penetration of M6G is mandatory to produce antinociception since naloxone but not naloxone methiodide (which does not enter brain from blood) was shown to block the analgesic effect of M6G (Wu et al., 1997). Despite similar pharmacokinetic properties, M6G and morphine differ in their lipid solubility. M6G was reported to have a 200-fold lower lipid solubility than morphine (Wu et al., 1997). The increased polarity of the glucuronide metabolite M6G also limits its diffusion through biologic membranes (Milne et al., 1997). Hence, to cross the BBB, M6G was shown to use the glucose transporter 1 transporters, albeit with a weak capacity. As opposed to morphine, M6G was, however, shown to be a poor P-glycoprotein (P-gp) substrate, which might explain its longer duration of effect as well as its higher potency when it reaches the brain (Bourasset et al., 2003).

When administrated to patients, morphine also produces a number of unwanted and debilitating effects, including constipation, nausea, respiratory depression, drowsiness, 
and tolerance (Benyamin et al., 2008). Interestingly, previous studies suggest that M6G is devoid of or exhibits fewer adverse effects compared with morphine. For instance, in a randomized double blind study of patients undergoing major joint replacement, M6G showed a higher analgesic potency with less respiratory suppression and somnolence compared with morphine (Penson et al., 2000; Hanna et al., 2005). Furthermore, in a study with healthy volunteers, the frequency of nausea, itching, and rash after M6G was significantly reduced compared with morphine (Hanna et al., 1991). M6G was also found devoid of nausea, vomiting, and sedation in cancer patients (Osborne et al., 1992). Finally, a study by Cann et al. (2002), in which 144 women received either $\mathrm{M} 6 \mathrm{G}$ or morphine as part of general anesthesia for day-case surgery, revealed that $\mathrm{M} 6 \mathrm{G}$ has a better safety profile than morphine. To see whether a parallel decrease in the unwanted effect of An2-M6G could be observed, we compared the effect of An2-M6G on the gastrointestinal tract motility to that of morphine and M6G. Using the charcoal meal test, we found that conjugation of morphine to An2 does not prevent the effect on the gastrointestinal tract. Indeed, at equivalent dose of morphine, An2-morphine significantly reduced the gastrointestinal transit of the charcoal meal. By contrast, An2-M6G, even at $20 \mathrm{mg} / \mathrm{kg}$ (equivalent to $5 \mathrm{mg} / \mathrm{kg}$ of morphine) did not significantly reduce the motility of the gastrointestinal tract. This is of particular interest because this dose of An2-M6G produced a maximal and sustained antinociception effect in the acute pain test, further supporting that improving the $\mathrm{BBB}$ penetration of opioids has the potential to improve their therapeutic profile. The conjugation of M6G or morphine to An2 may also offer additional benefits, such as reduction of analgesic tolerance. Indeed, previous studies support the idea that the development of morphine tolerance is partly due to an increase in the expression level of the drug transporter, P-gp, which decreases the morphine brain concentration (Ochiai et al., 2016). Accordingly, the brain uptake and the analgesic effect of morphine are increased in P-gp knockout mice (Hamabe et al., 2006, 2007). Consequently, the active transport of An2-M6G or An2-morphine by LRP1 receptor-mediated transcytosis may limit the development of tolerance.

In conclusion, our results demonstrate that the conjugation of M6G with BBB-penetrating peptides, such as An2, presents many advantages over the use of morphine: 1 ) improvement of the brain penetration of $\mathrm{M} 6 \mathrm{G}$, which results in a significant increase in its analgesic potency as well as duration of antinociceptive action; 2) a more favorable side effect profile that includes reduction of the risk of developing constipation when compared with morphine; 3) elimination of the interindividual variability in morphine analgesic response; and finally, 4) prevention of the adverse effects associated with the accumulation of the major metabolite of morphine (i.e., M3G). Altogether, these results indicate that the An2-M6G conjugate exhibits a unique pharmacodynamic profile with a better therapeutic window than morphine, which makes it an attractive option for developing painrelieving medications.

\section{Authorship Contributions}

Participated in research design: Demeule, Sarret, Gendron.

Conducted experiments: Otis, Belleville, Yang, Larocque, Régina.

Performed data analysis: Eiselt.
Wrote or contributed to the writing of the manuscript: Eiselt, Gendron, Sarret with the contributions of all authors.

\section{References}

Andersen G, Christrup L, and Sjøgren P (2003) Relationships among morphine metabolism, pain and side effects during long-term treatment: an update. J Pain Symptom Manage 25:74-91.

Balch RJ and Trescot A (2010) Extended-release morphine sulfate in treatment of severe acute and chronic pain. J Pain Res 3:191-200.

Banks WA (2016) From blood-brain barrier to blood-brain interface: new opportunities for CNS drug delivery. Nat Rev Drug Discov 15:275-292.

Banks WA and Kastin AJ (1994) Opposite direction of transport across the bloodbrain barrier for Tyr-MIF-1 and MIF-1: comparison with morphine. Peptides 15: 23-29.

Bastami S, Gupta A, Zackrisson A-L, Ahlner J, Osman A, and Uppugunduri S (2014) Influence of UGT2B7, OPRM1 and ABCB1 gene polymorphisms on postoperative morphine consumption. Basic Clin Pharmacol Toxicol 115:423-431.

Benyamin R, Trescot AM, Datta S, Buenaventura R, Adlaka R, Sehgal N, Glaser SE, and Vallejo R (2008) Opioid complications and side effects. Pain Physician 11(2 Suppl):S105-S120.

Bertrand Y, Currie J-C, Demeule M, Régina A, Ché C, Abulrob A, Fatehi D, Sartelet H, Gabathuler R, Castaigne J-P, et al. (2010) Transport characteristics of a novel peptide platform for CNS therapeutics. J Cell Mol Med 14:2827-2839.

Bertrand Y, Currie J-C, Poirier J, Demeule M, Abulrob A, Fatehi D, Stanimirovic D, Sartelet H, Castaigne J-P, and Béliveau R (2011) Influence of glioma tumour microenvironment on the transport of ANG1005 via low-density lipoprotein receptor-related protein 1. Br J Cancer 105:1697-1707.

Bhimji SS and Whitten R (2018) Opioid Induced Constipation. StatPearls [Internet], StatPearls Publishing, Treasure Island, FL.

Bickel U, Schumacher OP, Kang YS, and Voigt K (1996) Poor permeability of morphine 3-glucuronide and morphine 6-glucuronide through the blood-brain barrier in the rat. J Pharmacol Exp Ther 278:107-113.

Bourasset F, Cisternino S, Temsamani J, and Scherrmann J-M (2003) Evidence for an active transport of morphine-6-beta-d-glucuronide but not P-glycoprotein-mediated at the blood-brain barrier. J Neurochem 86:1564-1567.

Cann C, Curran J, Milner T, and Ho B (2002) Unwanted effects of morphine-6glucoronide and morphine. Anaesthesia 57:1200-1203.

Carrupt PA, Testa B, Bechalany A, el Tayar N, Descas P, and Perrissoud D (1991) Morphine 6-glucuronide and morphine 3-glucuronide as molecular chameleons with unexpected lipophilicity. J Med Chem 34:1272-1275.

Chen ZR, Irvine RJ, Somogyi AA, and Bochner F (1991) Mu receptor binding of some commonly used opioids and their metabolites. Life Sci 48:2165-2171.

Dagenais C, Rousselle C, Pollack GM, and Scherrmann JM (2000) Development of an in situ mouse brain perfusion model and its application to mdr1a P-glycoproteindeficient mice. J Cereb Blood Flow Metab 20:381-386.

De Gregori S, De Gregori M, Ranzani GN, Allegri M, Minella C, and Regazzi M (2012) Morphine metabolism, transport and brain disposition. Metab Brain Dis 27:1-5.

Demeule M, Beaudet N, Régina A, Besserer-Offroy É, Murza A, Tétreault P, Belleville K, Ché C, Larocque A, Thiot C, et al. (2014) Conjugation of a brain-penetrant peptide with neurotensin provides antinociceptive properties. J Clin Invest 124: $1199-1213$

Demeule M, Régina A, Ché C, Poirier J, Nguyen T, Gabathuler R, Castaigne J-P, and Béliveau R (2008) Identification and design of peptides as a new drug delivery system for the brain. J Pharmacol Exp Ther 324:1064-1072.

Due MR, Piekarz AD, Wilson N, Feldman P, Ripsch MS, Chavez S, Yin H, Khanna R, and White FA (2012) Neuroexcitatory effects of morphine-3-glucuronide are dependent on Toll-like receptor 4 signaling. J Neuroinflammation 9:200

Eiselt E, Côté J, Longpré J-M, Blais V, Sarret P, and Gendron L (2019) The combination of opioid and neurotensin receptor agonists improves their analgesic/adverse effect ratio. Eur J Pharmacol 848:80-87.

Hamabe W, Maeda T, Fukazawa Y, Kumamoto K, Shang LQ, Yamamoto A, Yamamoto C, Tokuyama S, and Kishioka S (2006) P-glycoprotein ATPase activating effect of opioid analgesics and their P-glycoprotein-dependent antinociception in mice. Pharmacol Biochem Behav 85:629-636.

Hamabe W, Maeda T, Kiguchi N, Yamamoto C, Tokuyama S, and Kishioka S (2007) Negative relationship between morphine analgesia and P-glycoprotein expression levels in the brain. J Pharmacol Sci 105:353-360.

Hanna MH, Elliott KM, and Fung M (2005) Randomized, double-blind study of the analgesic efficacy of morphine-6-glucuronide versus morphine sulfate for postoperative pain in major surgery. Anesthesiology 102:815-821.

Hanna MH, Peat SJ, Knibb AA, and Fung C (1991) Disposition of morphine-6glucuronide and morphine in healthy volunteers. $\mathrm{Br} J$ Anaesth 66:103-107.

Holzer P (2009) Opioid receptors in the gastrointestinal tract. Regul Pept 155:11-17.

Klepstad P, Dale O, Kaasa S, Zahlsen K, Aamo T, Fayers P, and Borchgrevink PC (2003) Influences on serum concentrations of morphine, M6G and M3G during routine clinical drug monitoring: a prospective survey in 300 adult cancer patients. Acta Anaesthesiol Scand 47:725-731.

Klimas R and Mikus G (2014) Morphine-6-glucuronide is responsible for the analgesic effect after morphine administration: a quantitative review of morphine, morphine-6-glucuronide, and morphine-3-glucuronide. Br J Anaesth 113:935-944

Koyyalagunta D (2007) Opioid analgesics, in Pain Management (Waldman SD and Bloch JI eds) pp 939-964, W.B. Saunders, Philadelphia.

Lacy C and Sainsbury M (1995) A synthesis of morphine-6-glucuronide. Tetrahedron Lett 36:3949-3950.

Lipkowski AW, Carr DB, Langlade A, Osgood PF, and Szyfelbein SK (1994) Morphine-3-glucuronide: silent regulator of morphine actions. Life Sci 55:149-154.

McAllister MS, Krizanac-Bengez L, Macchia F, Naftalin RJ, Pedley KC, Mayberg MR, Marroni M, Leaman S, Stanness KA, and Janigro D (2001) Mechanisms of glucose transport at the blood-brain barrier: an in vitro study. Brain Res 904:20-30. 
Mercadante S and Fulfaro F (2005) World Health Organization guidelines for cancer pain: a reappraisal. Ann Oncol 16 (Suppl 4):iv132-iv135.

Milne RW, Jensen RH, Larsen C, Evans AM, and Nation RL (1997) Comparison of the disposition of hepatically-generated morphine-3-glucuronide and morphine-6glucuronide in isolated perfused liver from the Guinea pig. Pharm Res 14 1014-1018.

Ochiai W, Kaneta M, Nagae M, Yuzuhara A, Li X, Suzuki H, Hanagata M, Kitaoka S, Suto W, Kusunoki Y, et al. (2016) Mice with neuropathic pain exhibit morphine tolerance due to a decrease in the morphine concentration in the brain. Eur J Pharm Sci 92:298-304.

Oldendorf WH, Hyman S, Braun L, and Oldendorf SZ (1972) Blood-brain barrier: penetration of morphine, codeine, heroin, and methadone after carotid injection. Science 178:984-986.

Osborne R, Joel S, Trew D, and Slevin M (1990) Morphine and metabolite behavior after different routes of morphine administration: demonstration of the importance of the active metabolite morphine-6-glucuronide. Clin Pharmacol Ther 47:12-19.

Osborne R, Thompson P, Joel S, Trew D, Patel N, and Slevin M (1992) The analgesic activity of morphine-6-glucuronide. Br J Clin Pharmacol 34:130-138.

Pasternak GW and Pan Y-X (2013) Mu opioids and their receptors: evolution of a concept. Pharmacol Rev 65:1257-1317.

Paul D, Standifer KM, Inturrisi CE, and Pasternak GW (1989) Pharmacological characterization of morphine- 6 beta-glucuronide, a very potent morphine metabolite. J Pharmacol Exp Ther 251:477-483.

Penson RT, Joel SP, Bakhshi K, Clark SJ, Langford RM, and Slevin ML (2000) Randomized placebo-controlled trial of the activity of the morphine glucuronides. Clin Pharmacol Ther 68:667-676.

Régina A, Demeule M, Ché C, Lavallée I, Poirier J, Gabathuler R, Béliveau R, and Castaigne J-P (2008) Antitumour activity of ANG1005, a conjugate between paclitaxel and the new brain delivery vector Angiopep-2. $\mathrm{Br} J$ Pharmacol 155 $185-197$.

Roeckel L-A, Utard V, Reiss D, Mouheiche J, Maurin H, Robé A, Audouard E, Wood JN, Goumon Y, Simonin F, et al. (2017) Morphine-induced hyperalgesia involves mu opioid receptors and the metabolite morphine-3-glucuronide. Sci Rep 7:10406.

Rukhman I, Yudovich L, Nisnevich G, and Gutman AL (2001) Selective synthesis of both isomers of morphine 6 - $\beta$-d-glucuronide and their analogs. Tetrahedron 57: 1083-1092.

Shavit Y, Wolf G, Goshen I, Livshits D, and Yirmiya R (2005) Interleukin-1 antagonizes morphine analgesia and underlies morphine tolerance. Pain 115:50-59.
Shimomura K, Kamata O, Ueki S, Ida S, Oguri K, Yoshimura H, and Tsukamoto $\mathrm{H}$ (1971) Analgesic effect of morphine glucuronides. Tohoku J Exp Med 105: $45-52$.

Smith GD and Smith MT (1995) Morphine-3-glucuronide: evidence to support its putative role in the development of tolerance to the antinociceptive effects of morphine in the rat. Pain 62:51-60.

Smith MT (2000) Neuroexcitatory effects of morphine and hydromorphone: evidence implicating the 3-glucuronide metabolites. Clin Exp Pharmacol Physiol 27: $524-528$

Sverrisdóttir E, Lund TM, Olesen AE, Drewes AM, Christrup LL, and Kreilgaard M (2015) A review of morphine and morphine-6-glucuronide's pharmacokineticpharmacodynamic relationships in experimental and clinical pain. Eur J Pharm Sci 74:45-62.

Thomas FC, Taskar K, Rudraraju V, Goda S, Thorsheim HR, Gaasch JA, Mittapalli RK, Palmieri D, Steeg PS, Lockman PR, et al. (2009) Uptake of ANG1005, a novel paclitaxel derivative, through the blood-brain barrier into brain and experimental brain metastases of breast cancer. Pharm Res 26:2486-2494.

Wu D, Kang YS, Bickel U, and Pardridge WM (1997) Blood-brain barrier permeability to morphine-6-glucuronide is markedly reduced compared with morphine Drug Metab Dispos 25:768-771.

Yang Z-Z, Li L, Wang L, Yuan L-M, Xu M-C, Gu J-K, Jiang HD, Yu L-S, and Zeng S (2017) The regioselective glucuronidation of morphine by dimerized human UGT2B7, 1A1, 1A9 and their allelic variants. Acta Pharmacol Sin 38:1184-1194.

Yeh SY (1975) Urinary excretion of morphine and its metabolites in morphinedependent subjects. J Pharmacol Exp Ther 192:201-210.

Yoshimura H, Îda S, Oguri K, and Tsukamoto H (1973) Biochemical basis for analgesic activity of morphine-6-glucuronide. I. Penetration of morphine-6-glucuronide in the brain of rats. Biochem Pharmacol 22:1423-1430.

Address correspondence to: Dr. Louis Gendron, Department of Pharmacology-Physiology, Faculty of Medicine and Health Sciences, Université de Sherbrooke, 3001, 12th Ave North, Sherbrooke, QC J1H 5N4, Canada. E-mail: Louis.Gendron@USherbrooke.ca; or Dr. Philippe Sarret, Department of Pharmacology-Physiology, Faculty of Medicine and Health Sciences, Université de Sherbrooke, 3001, 12th Ave North, Sherbrooke, QC J1H 5N4, Canada. E-mail: Philippe.Sarret@USherbrooke.ca 